\title{
HUBUNGAN ANTARA MINAT DAN MOTIVASI BELAJAR DENGAN HASIL BELAJAR IPA PADA SISWA SD
}

\author{
Ermelinda Yosefa Awe \\ Program Studi Pendidikan Guru Sekolah Dasar STKIP Citra Bakti, NTT \\ ermelindayosefaawe8@gmail.com \\ Kristina Benge \\ Program Studi Pendidikan Guru Sekolah Dasar STKIP Citra Bakti, NTT \\ kristinabenge@gmail.com
}

\begin{abstract}
Abstrak
Penelitian ini bertujuan untuk mengetahui hubungan antara minat belajar dan motivasi belajar dengan hasil belajar IPA pada siswa. Jenis penelitian ini adalah penelitian Ex-post facto. Populasi dalam penelitian ini adalah siswa/i kelas V SDI Bajawa yang berjumlah 42 orang. Sampel pada penelitian ini diambil dari keseluruhan jumlah populasi yang berjumlah 42 orang dengan persyaratan bahwa jika jumlah populasi mencapai 100 maka penelitian dikatakan penelitian populasi. Data dalam penelitian ini dikumpulkan dengan menggunakan kuesioner untuk variabel minat belajar dan motivasi belajar sedangkan hasil belajar menggunakan tes obyektif. Data dianalisis dengan menggunakan uji regresi sederhana dan uji-F. Hasil penelitian menunjukkan bahwa: (1) terdapat hubungan yang positif dan signifikan antara minat belajar dengan hasil belajar IPA pada siswa kelas V SDI Bajawa melalui persamaan regresi $\hat{Y}=17.335+0,040$ $\mathrm{X}_{1}$ dengan kontribusi sebesar $0,8 \%$ dan sumbangan efektifnya sebesar $0,01 \%$, (2) terdapat hubungan yang positif dan signifikan antara motivasi belajar dengan hasil belajar IPA pada siswa kelas V SDI Bajawa melalui persamaan regresi $\hat{\mathrm{Y}}=6.202+0,172 \mathrm{X}_{2}$ dengan kontribusi sebesar $9 \%$ dan sumbangan efektifnya sebesar $0,09 \%$, (3) terdapat hubungan yang positif dan signifikan secara bersama-sama antara minat dan motivasi belajar dengan hasil belajar IPA pada siswa kelas V SDI Bajawa melalui persamaan regresi $\hat{Y}=4.001+0,030 \mathrm{X}_{1}+0,170 \mathrm{X}_{2}$ dengan kontribusi sebesar 10,4\% dan sumbangan efektifnya sebesar $(\mathrm{SE}) 0,01=1 \%$. Berdasarkan hasil temuan tersebut dapat disimpulkan bahwa terdapat hubungan yang positif dan signifikan antara minat dan motivasi belajar dengan hasil belajar IPA pada siswa kelas V SDI Bajawa, Kecamatan Bajawa, Kabupaten Ngada. Dengan demikian kedua faktor tersebut dapat dijadikan prediktor tolak ukur keberhasilan belajar siswa khususnya pada mata pelajaran IPA dan mata pelajaran lain pada umumnya.
\end{abstract}

Kata-kata kunci: minat belajar, motivasi belajar dan hasil belajar IPA.

\begin{abstract}
This present study aimed at investigating the correlation between students' interest and motivation to the learning achievement on natural science subject of primary students. This study was in a form of ex-post facto. The population in this study was all fifth graders of SDI Bajawa in total of 42 students. These 42 students' were then used as the sample of the study. Further, the data were collected through questionnaire for the interests and learning motivation variables, while test was utilized to gather data on the learning achievement. In addition, the collected data were further analyzed by simple regression and F-test. The result of the study showed that (1) there is a positive and significant correlation between students' interest and the learning achievement which was shown by the following equation $\hat{Y}=17.335+0,040$ $\mathrm{X}_{1}$, and contributes by $0,8 \%$ and its significant contribution at $0.01 \%,(2)$ there is a positive and significant correlation between students' motivation and students' learning achievement which is shown by the following equation $\hat{Y}=6.202$ $+0,172 \mathrm{X}_{2}$, and contributes by $9 \%$ and its effective contribution at $0.09 \%$, (3) there is a positive and significant correlation between students' interest altogether with students' motivation and the natural science learning achievement which was shown by this equation $\hat{\mathrm{Y}}=4.001+0,030 \mathrm{X}_{1}+0,170 \mathrm{X}_{2}$ with contribution at $10.4 \%$ and its significant contribution by $0.01=1 \%$. Based on those calculations, it is concluded that there is a positive and significant correlation between students' interest and motivation to the students' learning achievement on natural science of the fifth graders of SDI Bajawa, Bajawa district, Ngada regency. Thus, those two factors has become predictors to the success of students' learning on natural science subject and other related subjects.
\end{abstract}

Keywords: Students’ Interest, Learning Motivation, Natural Science Learning Achievement 


\section{Pendahuluan}

Pendidikan adalah segala pengalaman belajar yang berlangsung dalam segala lingkungan dan sepanjang hidup. Dalam Undang-Undang RI nomor 20 tahun 2003 tentang Sistem Pendidikan Nasional menegaskan bahwa: Pendidikan adalah usaha sadar dan terencana untuk mewujudkan suasana belajar dan proses pembelajaran agar peserta didik secara aktif mengembangkan potensi dirinya untuk memiliki kekuatan spiritual keagamaan, pengendalian diri, kepribadian, kecerdasan, akhlak mulia, serta keterampilan yang diperlukan dirinya, masyarakat, bangsa dan negara.

Dalam hal ini berarti dalam praktik usahanya pendidikan bertujuan untuk mewujudkan suasana belajar yang aktif sehingga dapat meningkatkan segala potensi yang ada dalam diri siswa. Meningkatkan pertumbuhan dan perkembangan siswa dapat dilakukan dengan cara memberikan pengajaran, bimbingan, latihan atau pembiasaan yang diarahkan dalam rangka mengembangkan kepribadian dan kemampuan siswa ke arah yang lebih baik.

Melalui pendidikan diharapkan dapat mencetak generasi berkualitas yang akan berkontribusi dalam tercapainya pembangunan nasional. Dalam Pasal 3 Undang-Undang Nomor 20 Tahun 2003 tentang Sistem Pendidikan Nasional disebutkan bahwa: Pendidikan nasional berfungsi mengembangkan kemampuan dan membentuk watak serta peradaban bangsa yang bermartabat dalam rangka mencerdaskan kehidupan bangsa, bertujuan untuk berkembangnya potensi peserta didik agar menjadi manusia yang beriman dan bertakwa kepada Tuhan Yang Maha Esa, berakhlak mulia, sehat, berilmu, cakap, kreatif, mandiri, dan menjadi warga negara yang demokratis serta bertanggung jawab. Untuk mewujudkan tujuan pendidikan nasional perlu diimbangi dengan peningkatan mutu pendidikan.

Mutu pendidikan sangatlah erat kaitannya dengan mutu guru dan mutu siswa. Guru sebagai pengelola kegiatan pembelajaran merupakan faktor penentu kunci keberhasilan dalam pelaksanaan pendidikan. Seorang guru yang profesional tidak cukup hanya dengan menguasai materi pelajaran saja, akan tetapi seorang guru harus mampu mengayomi, menjadi contoh, dan selalu mendorong siswa untuk lebih baik dan maju.

Selain faktor guru, dalam mewujudkan peningkatan mutu pendidikan juga tidak terlepas dari faktor siswa karena siswa merupakan titik pusat proses pembelajaran. Oleh karena itu, dalam meningkatkan mutu pendidikan haruslah pula diikuti dengan peningkatan mutu siswa. Peningkatan mutu siswa dapat dilihat pada tingkat hasil belajar siswa. Menurut Susanto (2013: 5) hasil belajar merupakan perubahan yang terjadi pada diri siswa, baik yang menyangkut aspek kognitif, afektif, dan psikomotor sebagai hasil dari belajar. Pengertian tentang hasil belajar dipertegas oleh Nawawi (Susanto, 2013: 5) yang menyatakan bahwa hasil belajar dapat diartikan sebagai tingkat keberhasilan siswa dalam mempelajari materi pelajaran di sekolah yang dinyatakan dalam skor yang diperoleh dari hasil tes mengenai sejumlah materi pelajaran tertentu.

Bagi seorang siswa mendapatkan hasil belajar yang baik merupakan sebuah kebanggaan. Siswa yang mendapatkan hasil belajar yang baik akan selalu berusaha untuk menjaga dan meningkatkan hasil belajar yang telah diperolehnya. Akan tetapi, untuk mendapatkan hasil belajar yang baik bukanlah hal yang mudah, karena keberhasilan belajar siswa dipengaruhi oleh beberapa faktor dan memerlukan usaha yang besar untuk meraihnya. Menurut Dalyono (2012: 55) berhasil atau tidaknya seseorang dalam belajar disebabkan beberapa faktor yang mempengaruhi pencapaian hasil belajar yaitu berasal dari dalam diri orang yang belajar (internal) meliputi kesehatan, intelegensi dan bakat, minat dan motivasi, dan cara belajar serta ada pula dari luar dirinya (eksternal) meliputi lingkungan keluarga, sekolah, masyarakat, dan lingkungan sekitar. Satu diantara faktor yang berasal dari dalam diri siswa yang belajar adalah minat dan motivasi. Menurut Djamarah (2008: 132) "minat adalah kecenderungan yang menetap untuk memperhatikan dan mengenang beberapa aktivitas. Seseorang yang berminat dengan aktivitas akan memperhatikan aktivitas itu secara konsisten dengan rasa senang." Crow dan Crow (Djaali, 2007: 121) mengatakan bahwa minat berhubungan dengan gaya gerak yang mendorong seseorang untuk menghadapi atau berurusan dengan orang lain, benda, kegiatan, pengalaman yang dirangsang oleh kegiatan itu sendiri.

Menurut Sardiman (2012: 75) motivasi adalah keseluruhan daya penggerak di dalam diri siswa yang menimbulkan kegiatan belajar yang menjamin kelangsungan dari kegiatan belajar dan memberikan arah sehingga tujuan yang dikehendaki dapat tercapai. Menurut Sardiman (2012: 75) seorang siswa yang memiliki intelegensi cukup tinggi, boleh jadi gagal karena kekurangan motivasi. Setiap siswa memiliki motivasi belajar yang berbeda, ada yang tinggi dan rendah. Oleh karena itu, minat dan motivasi belajar 
siswa harus selalu ditumbuhkan karena kegagalan dalam belajar tidak hanya disebabkan oleh pihak siswa, tetapi mungkin dari guru yang tidak berhasil menumbuhkan motivasi belajar siswa sehingga minat belajar siswa menurun dan semangat belajar menjadi semakin berkurang. Sehingga seorang guru dituntut agar mampu berperan sebagai motivator yang sangat berperan penting dalam meningkatkan kegairahan dan pengembangan kegiatan belajar siswa.

Agar proses pembelajaran dapat berjalan dengan efektif, guru harus meningkatkan kesempatan belajar bagi siswa baik kualitas maupun kuantitas. Kesempatan belajar siswa dapat ditingkatkan dengan cara melibatkan siswa secara aktif dalam belajar. Guru harus menunjukkan keseriusan saat mengajar sehingga dapat membangkitkan minat serta motivasi siswa untuk belajar. Selain itu guru harus mengetahui tentang objek yang akan diajarnya sehingga dapat mengajarkan materi pembelajaran dengan penuh dinamika dan inovasi. Demikian halnya dengan pembelajaran Ilmu Pengetahuan Alam (IPA) di Sekolah dasar. Guru perlu memahami hakikat pembelajaran IPA.

Menurut Prihantoro (dalam kutipan Trianto, 2014: 137) mengatakan IPA hakekatnya merupakan suatu produk, proses, dan aplikasi. Sebagai produk IPA merupakan sekumpulan pengetahuan dan sekumpulan konsep dan bagian konsep. Sebagai suatu proses IPA merupakan proses yang dipergunakan untuk mempelajari obyek studi, menemukan dan mengembangkan produk-produk sains, dan sebagai aplikasi teori-teori IPA akan melahirkan teknologi yang dapat memberi kemudahan bagi kehidupan. Mata pelajaran IPA atau sains merupakan salah satu mata pelajaran yang diajarkan di Sekolah dasar. Mata pelajaran ini dirasakan sebagai mata pelajaran yang kurang menarik bagi siswa dan membosankan, karena cakupan dari materi ini sangat luas. Mata pelajaran IPA yang diajarkan di Sekolah dasar merupakan suatu mata pelajaran yang berisikan ilmu yang natural atau alami yang meliputi: makhluk hidup, manusia, tanaman, hewan dan hal-hal yang menyangkut pertumbuhan atau perkembangan pada makhluk hidup serta hal yang berkaitan dengan Alam. Jadi dalam mengajarkan pelajaran IPA, guru dituntut untuk bisa membantu siswa agar dapat memahami suatu materi pelajaran dengan cara memperlihatkan atau mempraktekkan secara langsung kejadian atau hal-hal yang terdapat dalam materi tersebut.

Ilmu Pengetahuan Alam (IPA) berhubungan dengan cara mencari tahu tentang alam secara sistematis, sehingga bukan hanya penguasaan kumpulan pengetahuan yang berupa fakta-fakta, konsepkonsep, atau prinsip-prinsip saja tetapi juga merupakan suatu proses penemuan. Selain itu IPA juga merupakan ilmu yang bersifat empirik dan membahas tentang fakta serta gejala alam. Fakta dan gejala alam tersebut menjadikan pembelajaran IPA tidak hanya verbal tetapi juga faktual. Pembelajaran IPA di SD diharapkan dapat menjadi wahana bagi siswa untuk mempelajari dirinya sendiri dan alam sekitar, serta prospek pengembangan lebih lanjut dalam menerapkannnya dalam kehidupan sehari-hari. Untuk itu pembelajaran IPA menekankan pada pemberian pengalaman secara langsung.

Namun demikian fakta empiris di lapangan menunjukkan bahwa pembelajaran IPA masih banyak yang diajarkan dengan metode yang tidak sesuai dengan karakteristik mata pelajaran IPA (Laksana, 2017). Dalam proses pembelajaran, siswa kurang didorong untuk mengembangkan kemampuan berfikirnya. Proses pembelajaran di kelas kebanyakan di arahkan pada kemampuan siswa untuk menghafal informasi, otak anak dipaksa untuk mengingat dan menimbun berbagai informasi tanpa dituntut untuk menghubungkannya dengan kehidupan sehari-hari. Proses pembelajaran yang seperti itu akan membuat siswa cepat bosan dalam mengikuti pembelajaran di kelas. Mereka sering tidak memperhatikan pelajaran bahkan mereka terkadang malah bermain atau berbicara dengan teman ketika proses pembelajaran sedang berlangsung sehingga kelas menjadi gaduh dan pelajaran yang disampaikan oleh guru menjadi tidak efektif.

Kondisi pembelajaran yang demikian juga terjadi di SD Inpres Bajawa. Berdasarkan observasi pendahuluan, terdapat beberapa kendala yang dihadapi dalam proses pembelajaran IPA, salah satunya adalah kurangnya pemahaman siswa dengan materi-materi yang diajarkan oleh guru. Kondisi tersebut disebabkan oleh berbagai hal, diantaranya yaitu: 1) siswa kurang memperhatikan materi yang disampaikan karena muncul rasa bosan dengan model pembelajaran yang monoton yaitu lebih banyak didominasi oleh guru dan siswa pandai saja, sedangkan siswa yang kurang pandai cenderung pasif, 2) siswa tidak terlalu menyukai pelajaran IPA karena menganggap bahwa IPA adalah mata pelajaran yang sulit dimengerti, 3) dalam proses belajar mengajar selama ini hanya sebatas pada upaya menjadikan anak mampu dan terampil mengerjakan soal-soal yang ada sehingga pembelajaran yang berlangsung kurang bermakna dan terasa membosankan bagi siswa. Hal ini apabila dibiarkan terus menerus akan mengakibatkan tidak tercapainya tujuan pembelajaran seperti yang diharapkan. 
Berdasarkan hasil observasi dan wawancara dengan Guru kelas pada kegiatan penelitian pendahuluan yang dilakukan di kelas V SDI Bajawa, saat proses pembelajaran IPA menunjukan bahwa minat dan motivasi belajar siswa masih rendah. Hal ini dilihat dari siswa yang kurang memperhatikan penjelasan guru, mereka tidak konsentrasi saat pembelajaran berlangsung, tidak ikut aktif dalam pembelajaran, dan duduk dengan posisi yang tidak benar, hal ini mengindikasikan bahwa siswa tidak bersemangat dan tidak bersungguh-sungguh dalam mengikuti pelajaran IPA. Hal ini menunjukkan bahwa siswa belum memiliki dorongan dan minat dalam belajar. Faktor lain yang membuat minat dan motivasi belajar siswa rendah adalah metode pembelajaran yang digunakan guru saat menjelaskan materi pelajaran belum tepat. Selama proses pembelajaran guru menggunakan metode yang bersifat monoton yaitu terpusat pada guru dan belum melibatkan siswa. Sedangkan, saat proses pembelajaran yang lain seperti mata pelajaran IPS siswa terlihat lebih semangat, walaupun terkadang masih ada siswa yang belum berkonsentrasi dan terlibat aktif. Hal ini menunjukkan bahwa belum adanya kegiatan belajar yang menarik.

Selain hasil observasi dan wawancara diperoleh juga nilai yang dicapai siswa kelas $\mathrm{V}$ pada mata pelajaran IPA juga belum maksimal sesuai dengan KKM yang ditetapkan. IPA sebenarnya tidaklah sulit dan dalam pembelajaran IPA siswa perlu untuk dapat bereksperimen dan bisa menemukan sendiri mengenai apa yang dipelajarinya. Akan tetapi, siswa tidak begitu antusias, sehingga membuat siswa menjadi malas dan kurang bersemangat dalam mengikuti kegiatan pembelajaran. Hal ini menunjukkan belum adanya hasrat dan keinginan siswa untuk berhasil.

Selain itu, minimnya penggunaan media pembelajaran oleh guru saat melaksanakan kegiatan pembelajaran di dalam kelas yang ada di SDI Bajawa membuat siswa sulit memahami materi pelajaran IPA. Jumlah media IPA yang ada cukup memadai seperti gambar yang mudah didapat di lingkungan sekolah, hanya saja kurang kreatifnya guru ataupun motivasi dan minat siswa pada pelajaran IPA yang kurang. Kondisi yang berbeda terjadi pada proses pembelajaran yang lain. Siswa terlihat lebih semangat dan aktif untuk mengikuti kegiatan pembelajaran, salah satunya seperti pada mata pelajaran Penjas. Hal itu, karena siswa dapat terlibat langsung saat praktek, sehingga mudah memahami materi pelajaran. Dikatakan juga di SDI Bajawa, siswa lebih menyukai mata pelajaran lain seperti Penjas Orkes yang lebih banyak diluar kelas dari pada IPA karena siswa kurang berminat pada mata pelajaran IPA ditambah lagi karena kurangnya motivasi siswa, sehingga membuat mereka malas untuk belajar. Hal ini menunjukkan kurangnya hasrat dan keinginan siswa untuk berhasil. Itulah hasil temuan-temuan yang diperoleh dari penelitian pendahuluan di SDI Bajawa yang menjadi indikasi minat dan motivasi belajar yang rendah adalah faktor yang membuat hasil belajar IPA pada siswa kelas V SDI Bajawa masih rendah. Ditambah dengan bukti dari nilai ujian mid semester ganjil pada mata pelajaran IPA tahun pelajaran 2016/2017 masih tergolong rendah.

Dari permasalahan dan hasil pemikiran yang telah dipaparkan di atas, maka dilakukan penelitian mengenai "Hubungan Antara Minat dan Motivasi Belajar Dengan Hasil Belajar IPA Pada Siswa Kelas V SDI Bajawa Tahun Pelajaran 2016/2017”.

Berdasarkan uraian dari latar belakang di atas, maka dapat dikemukakan rumusan masalah sebagai berikut.

1) Apakah terdapat hubungan yang positif dan signifikan antara minat belajar dengan hasil belajar IPA pada siswa kelas V SD Inpres Bajawa Tahun ajaran 2016/2017?

2) Apakah terdapat hubungan yang positif dan signifikan antara motivasi belajar dengan hasil belajar IPA pada siswa kelas V SD Inpres Bajawa Tahun ajaran 2016/2017?

3) Apakah terdapat hubungan yang positif dan signifikan secara bersama-sama antara minat dan motivasi belajar dengan hasil belajar IPA pada siswa kelas V SD Inpres Bajawa Tahun ajaran 2016/2017?

Sesuai dengan permasalahan di atas, maka tujuan yang ingin dicapai dalam penelitian ini adalah sebagai berikut.

1) Untuk mengetahui hubungan yang positif dan signifikan antara minat belajar dengan hasil belajar IPA pada siswa kelas V SD Inpres Bajawa Tahun ajaran 2016/2017.

2) Untuk mengetahui hubungan yang positif dan signifikan antara motivasi belajar dengan hasil belajar IPA pada siswa kelas V SD Inpres Bajawa Tahun ajaran 2016/2017.

3) Untuk mengetahui hubungan yang positif dan signifikan secara bersama-sama antara minat dan motivasi belajar dengan hasil belajar IPA pada siswa kelas V SD Inpres Bajawa Tahun ajaran 2016/2017 


\section{Metode Penelitian}

Rancangan penelitian ini merupakan penelitian Ex Post Facto karena variabel bebas dalam penelitian ini tidak dikendalikan atau diperlakukan khusus melainkan hanya mengungkap fakta berdasarkan pengukuran gejala yang telah ada pada diri responden sebelum penelitian ini dilaksanakan.

Penelitian ini dilakukan di SDI Bajawa Kecamatan Bajawa Kabupaten Ngada. Populasi penelitian ini adalah seluruh siswa kelas VA dan VB SD Inpres Bajawa Tahun Pelajaran 2016/2017 yang berjumlah 42 orang. Arikunto (2006: 134) berpendapat bahwa apabila populasi kurang dari 100, maka sampel di ambil dari keseluruhan populasi yang ada sehingga disebut penelitian populasi. Berdasarkan pertimbangan pendapat ahli tersebut, maka jumlah sampel yang akan diambil dalam penelitian ini adalah keseluruhan dari jumlah populasi. Jumlah populasi sebesar 42 siswa, sehingga dengan demikian peneliti mengambil 100\% dari jumlah populasi atau penelitian populasi.

Sampel dalam penelitian ini diambil dari keseluruhan jumlah populasi Dalam hal ini jumlah populasi yaitu 42 siswa. Ini di karenakan jumlah populasi tidak mencapai 100\% seperti yang dijelaskan pada pengertian populasi di atas sehingga peneliti mengambil $100 \%$ dari jumlah populasi untuk dijadikan sampel maka jumlah sampel dalam penelitian ini adalah 42 siswa.

Sesuai dengan apa yang dicapai dalam penelitian ini, maka data yang telah terkumpul dari responden dianalisis dengan analisis statistik. Teknik analisis statistik dimulai dari statistik deskriptif untuk mengetahui berapa besar rerata skor, median, modus, simpangan baku serta distribusi frekuensi dari data yang telah terkumpulkan. Kegunaan statistik deskriptif ini adalah untuk menggambarkan suatu keadaan dengan apa adanya secara obyektif tanpa dipengaruhi dari dalam diri peneliti atau secara subyektif. Kemudian analisis yang digunakan untuk menguji hipotesis adalah teknik analisis korelasi sederhana dan uji F. Namun sebelum dilakukan analisis tersebut, terlebih dahulu dilakukan uji persyaratan analisis yaitu uji normalitas sebaran data, uji lineritas data dan uji multikolinearitas data. data dianalisis dengan menggunakan SPSS 16.0 Software for windows.

Data yang dikumpulkan dalam penelitian ini adalah data yang semuanya berbentuk data kuantitatif serta berbentuk data interval yang dikumpulkan melalui alat ukur berupa kuesioner yang digunakan untuk mengukur minat dan motivasi belajar dengan mengikuti pola Likert sedangkan untuk tes hasil belajar diukur dengan menggunakan tes. Sumber datanya adalah siswa-siswi kelas V SDI Bajawa yang akan menjadi anggota sampel.

\section{Hasil Penelitian dan Pembahasan}

Hipotesis yang diuji dalam penelitian ini adalah: (1) Terdapat hubungan yang positif dan signifikan antara minat belajar dengan hasil belajar IPA, (2) terdapat hubungan yang positif dan signifikan antara motivasi belajar dengan hasil belajar IPA, (3) terdapat hubungan yang positif dan signifikan secara bersama-sama antara minat dan motivasi belajar dengan hasil belajar IPA. Setelah dilakukan analisis diperoleh ringkasan hasil uji hipotesis seperti tampak pada tabel berikut.

Tabel 1. Ringkasan Hasil Uji Hipotesis Penelitian

\begin{tabular}{ccccccc}
\hline $\begin{array}{c}\text { Persamaan Garis } \\
\text { Regresi }\end{array}$ & $\mathbf{r}_{\mathbf{x y}}$ & $\mathbf{r}_{\mathbf{t a b}}$ & $\mathbf{R}_{\mathbf{y}}$ & $\mathbf{R}_{\mathbf{y}}{ }^{2}$ & $\mathbf{S E ~ ( \% )}$ & Ket \\
$\hat{\mathrm{Y}}=\begin{array}{c}17.335+0,040 \\
\mathrm{X}_{1}\end{array}$ & 0,391 & 0,304 & - & - & 0,01 & Signifikan \\
$\hat{\mathrm{Y}}=\begin{array}{c}6.202+0,172 \\
\mathrm{X}_{2}\end{array}$ & 0,314 & 0,304 & - & - & 0,09 & Signifikan \\
$\hat{\mathrm{Y}}=4.001+$ & - & - & 0,322 & 0,103 & - & Signifikan \\
$0,030 \mathrm{X}_{1}+0,170 \mathrm{X}_{2}$ & & & & & &
\end{tabular}

Keterangan:

$\mathrm{X}_{1}=$ Skor minat belajar

$\mathrm{X}_{2}=$ Skor motivasi belajar

$\mathrm{Y}=$ Skor hasil belajar 
Hipotesis pertama menyatakan bahwa terdapat hubungan yang signifikan antara minat belajar dengan hasil belajar IPA. Dari tabel 4.1 di atas maka dapat diketahui persamaan Regresi $\mathrm{Y}_{\text {atas }} \mathrm{X}_{1}$ adalah $\hat{\mathrm{Y}}=17.335+0,040 \mathrm{X}_{1}$. Berdasarkan analisis dengan menggunakan SPSS besarnya $\mathrm{r}_{\text {hitung }}=0,391$ dengan $\mathrm{R}^{2}$ $=1528=15,28 \%$ dan di konsultasikan dengan $\mathrm{r}_{\text {tabel }}$ product moment $\mathrm{n}=42=0,304$, signifikan pada $\alpha=$ 0,05. Hal ini berarti hipotesis penelitian $\left(\mathrm{H}_{\mathrm{a}}\right)$ yang diajukan, yaitu "terdapat hubungan yang signifikan antara minat belajar dengan hasil belajar IPA. Berdasarkan hasil analisis tersebut dapat disimpulkan bahwa terdapat hubungan yang signifikan antara minat belajar dengan hasil belajar IPA melalui persamaan regresi $\hat{\mathrm{Y}}=17.335+0,040 \mathrm{X}_{1}$ dengan kontribusi sebesar $0,8 \%$ dan sumbangan efektifnya sebesar $0,01 \%$. Hal ini berarti makin tinggi minat belajar siswa maka makin tinggi pula hasil belajar IPA siswa. Sumbangan efektif (SE) variabel minat belajar dengan hasil belajar IPA sebesar 0,01\%. Dengan demikian, minat belajar tidak terlepas sebagai faktor yang berkontribusi dengan hasil belajar IPA.

Slameto (2010: 180) menyatakan minat adalah suatu rasa lebih suka atau rasa ketertarikan pada suatu hal atau aktivitas, tanpa ada yang menyuruh. Seseorang yang berminat dengan aktivitas akan memperhatikan aktivitas itu secara konsisten dengan rasa senang. Sejalan dengan Slameto, Djamarah (2008 : 13) berpendapat minat adalah kecenderungan yang menetap untuk memperhatikan dan mengenang beberapa aktivitas. Minat yang dimaksudkan disini adalah minat yang berhubungan dengan belajar. Dimana menurut Slameto $(2010: 2)$ belajar adalah suatu proses usaha yang dilakukan individu untuk memperoleh suatu perubahan tingkah laku yang baru secara keseluruhan, sebagai hasil pengalaman individu itu sendiri dalam interaksi dengan lingkungannya.

Minat merupakan dasar yang paling penting dalam keberhasilan proses pembelajaran. Jika siswa merasa senang dengan suatu mata pelajaran maka ia akan dengan cepat mengerti dan memahami materi yang diberikan oleh guru. Karena minat menjadikan siswa cenderung tetap untuk memperhatikan dan mempunyai hubungan yang besar tehadap kegiatan pembelajaran, karena bila bahan pelajaran yang tidak sesuai dengan minat siswa, maka mereka tidak belajar dengan sebaik-baiknya. Jadi apabila seseorang yang menaruh minat dengan sesuatu mata pelajaran berarti individu tersebut terdapat motivasi yang menyebabkan secara aktif dengan hal yang menarik perhatiannya.

Dengan memperhatikan teori pendukung yang digunakan sebagai pijakan dalam merumuskan hipotesis seperti yang telah dipaparkan di atas, dugaan yang menyatakan bahwa minat belajar berkontribusi dengan hasil belajar telah terbukti secara empirik dalam penelitian ini. Dengan demikian dugaaan yang menyatakan terdapat kontribusi yang signifikan minat belajar dengan belajar IPA telah terbukti secara empirik dalam penelitian ini.

Hipotesis kedua menyatakan bahwa terdapat hubungan yang signifikan motivasi belajar $\left(\mathrm{X}_{2}\right)$ dengan hasil belajar IPA (Y). Berdasarkan tabel 4.1 di atas dapat diketahui persamaan regresi $\mathrm{Y}_{\text {atas }} \mathrm{X}_{2}$ adalah $\hat{\mathrm{Y}}=6.202+0,172 \mathrm{X}_{2}$. Berdasarkan analisis dengan menggunakan SPSS diperoleh besarnya $\mathrm{r}_{\text {hitung }}$ $=0,314$ dengan $\mathrm{R}^{2}=0,09=9 \%$, dan dikonsultasikan dengan $\mathrm{r}_{\text {tabel }}$ product moment $\mathrm{n}=42$ pada taraf signifikansi $0,05=0,304$. Ini berarti $r_{\text {hitung }}=0,314$ signifikan pada $\alpha=0,05$. Hal ini berarti hipotesis penelitian $\left(\mathrm{H}_{\mathrm{a}}\right)$ yang diajukan, yaitu "terdapat hubungan yang signifikan antara Motivasi Belajar dengan Hasil Belajar IPA. Berdasarkan hasil analisis tersebut dapat disimpulkan bahwa terdapat hubungan yang signifikan motivasi belajar dengan hasil belajar IPA melalui persamaan regresi $\hat{\mathrm{Y}}=6.202+0,172 \mathrm{X}_{2}$ dengan kontribusi sebesar $9 \%$ dan sumbangan efektifnya sebesar 0,09\%. Hasil penelitian ini sejalan dengan penelitian yang dilakukan oleh Repa Septia Ratiana tahun 2013 dengan judul Hubungan Antara Minat dan Motivasi Belajar dengan Hasil Belajar Biologi, Hasil penelitian menunjukan ada hubungan antara minat dengan hasil belajar dengan angka korelasi 0,628 berkategori kuat, ada hubungan antara motivasi belajar dengan hasil belajar dengan angka korelasi 0,716, berkategori kuat, ada hubungan antara minat dan motivasi belajar dengan hasil belajar dengan korelasi 0,817 berkategori kuat. Jadi, minat belajar dan motivasi belajar dengan hasil belajar memiliki hubungan, semakin baik minat dan motivasi belajar siswa maka semakin baik hasil belajar yang diperoleh siswa.

Motivasi belajar menurut Uno (2012: 23) adalah dorongan internal dan eksternal pada siswa-siswa yang sedang belajar untuk mengadakan perubahan tingkah laku, pada umumnya dengan beberapa indikator atau unsur yang mendukung. Oleh karena itu motivasi adalah satu faktor yang sangatlah penting dalam proses pembelajaran agar siswa lebih giat dalam belajar. Siswa yang merasa termotivasi akan sangat senang untuk belajar bahkan dalam mengerjakan tugas yang diberikan. Dengan demikian, hasil belajar yang di peroleh siswa yang diberi motivasi akan menjadi semakin meningkat. 
Korelasi/hubungan yang terjadi antara motivasi belajar dengan hasil belajar IPA adalah korelasi positif, yang berarti bahwa semakin tinggi motivasi belajar siswa maka makin meningkat pula hasil belajar IPA pada siswa setiap tahunnya.

Dengan memperhatikan teori pendukung yang digunakan sebagai pijakan dalam merumuskan hipotesis dan kajian penelitian yang relevan, seperti yang telah dipaparkan di atas dugaan yang menyatakan bahwa motivasi belajar dengan hasil belajar IPA telah terbukti secara empirik dalam penelitian ini. Dengan demikian dugaaan yang menyatakan terdapat kontribusi yang signifikan antara motivasi belajar dengan hasil belajar IPA telah terbukti secara empirik dalam penelitian ini. Hal ini mengidentifikasikan betapa pentingnya motivasi belajar dalam meningkatkan hasil belajar IPA.

Hipotesis ketiga menyatakan bahwa "terdapat hubungan yang signifikan secara simultan antara Minat $\left(\mathrm{X}_{1}\right)$ dan Motivasi Belajar $\left(\mathrm{X}_{2}\right)$ dengan hasil belajar IPA(Y). Dengan menggunakan SPSS diperoleh : $\mathrm{R}_{\mathrm{y}}(1,2)=0,322, \mathrm{R}^{2=} 0,104=10,4 \%$. Ini berarti secara bersama-sama minat belajar dan motivasi belajar dengan Hasil belajar IPA 10,4\% dengan persamaan regresi $\hat{Y}=4.001+0,030 \mathrm{X}_{1}+0,170 \mathrm{X}_{2}$. Berdasarkan hasil analisis tersebut dapat disimpulkan bahwa, terdapat hubungan yang positif dan signifikan secara bersama-sama antara minat belajar, motivasi belajar dengan hasil belajar IPA melalui persamaan regresi = $\hat{\mathrm{Y}}=4.001+0,030 \mathrm{X}_{1}+0,170 \mathrm{X}_{2}$ dengan kontribusi sebesar $10,4 \%$ dan sumbangan efektifnya sebesar (SE) $0,01=1 \%$.

Berdasarkan hasil tersebut, tampak dengan jelas bahwa dengan minat belajar yang tinggi dan baik, motivasi belajar yang kuat dan tinggi, maka hasil belajar yang diperoleh khususnya pada mata pelajaran IPA menjadi semakin meningkat. Dalam kegiatan belajar mengajar minat dan motivasi sangat dibutuhkan. Tanpa adanya minat dan motivasi, belajar akan menjadi sia-sia. Kekuatan hubungan kedua variabel bebas dengan hasil belajar IPA secara berurutan adalah minat belajar dan motivasi belajar. Hal ini berarti hipotesis penelitian $\left(\mathrm{H}_{\mathrm{a}}\right)$ yang diajukan yaitu "terdapat sontribusi yang signifikan secara bersama-sama antara minat belajar dan motivasi belajar dengan hasil belajar IPA"diterima .

\section{Menghitung Sumbangan Efektif}

$$
\begin{aligned}
& \text { SE } X_{1}=\frac{9.139}{117471}(0,103)=0,01 \% \\
& \text { SE } X_{2}=\frac{108.334}{117471}(0,103)=0,09 \%
\end{aligned}
$$

Total $0,1 \%$.

Sumbangan efektif secara keseluruhan variabel minat belajar dan motivasi belajar adalah $0,1 \%$ $\left(\mathrm{X}_{1}=0,01 \%+\mathrm{X}_{2}=0,09 \%\right)$ Dengan demikian berarti ada $0,01 \%$ hasil belajar IPA dipengaruhi oleh faktor lain yang tidak diteliti.

\section{Simpulan dan Saran}

Berdasarkan analisis dan hasil pembahasan dapat ditemukan hal-hal sebagai berikut. 1) Terdapat hubungan yang positif dan signifikan antara minat belajar dengan hasil belajar IPA pada siswa kelas V SDI Bajawa melalui persamaan regresi $\hat{Y}=17.335+0,040 \mathrm{X}_{1}$ dengan kontribusi sebesar $0.8 \%$ dan sumbangan efektifnya sebesar $0,01 \%$. 2) Terdapat hubungan yang positif dan signifikan antara motivasi belajar dengan hasil belajar IPA pada siswa kelas V SDI Bajawa melalui persamaan regresi $\hat{Y}=6.202+0,172 X_{2}$ dengan kontribusi sebesar $9 \%$ dan sumbangan efektifnya sebesar $0,09 \%$. 3) Terdapat hubungan yang positif dan signifikan secara bersama-sama antara minat dan motivasi belajar dengan hasil belajar IPA pada siswa kelas V SDI Bajawa melalui persamaan regresi $\hat{\mathrm{Y}}=4.001+0,030 \mathrm{X}_{1}+0,170 \mathrm{X}_{2}$ dengan kontribusi sebesar 10,4 $\%$ dan sumbangan efektifnya sebesar $(\mathrm{SE}) 0,01=1 \%$.

Berdasarkan hasil temuan tersebut dapat disimpulkan bahwa terdapat hubungan yang positif dan signifikan antara minat dan motivasi belajar dengan hasil belajar IPA pada siswa kelas V SDI Bajawa kecamatan Bajawa Kabupaten Ngada. Dengan demikian kedua faktor tersebut dapat dijadikan prediktor tolak ukur keberhasilan belajar siswa khususnya pada mata pelajaran IPA dan mata pelajaran lain pada umumnya. 
Berdasarkan hasil temuan hasil penelitian ini menunjukan bahwa variabel minat dan motivasi belajar berkontribusi secara signifikan dengan hasil belajar IPA pada siswa kelas V SDI Bajawa kecamatan Bajawa Kabupaten Ngada. Berdasarkan temuan tersebut, maka dapat disarankan beberapa hal kepada. 1) Kepala Sekolah Dasar Inpres Bajawa. Hasil temuan menunjukan bahwa minat dan motivasi belajar pada siswa kelas V SDI Bajawa belum optimal, maka disarankan agar untuk lebih memperhatikan minat dan juga motivasi belajar siswa agar hasil belajar yang diperoleh siswa setiap tahunnya semakin meningkat. 2) Guru Sekolah dan sekolah. Kepada guru sekolah dasar Inpres Bajawa, hendaknya hasil penelitian ini dijadikan masukan sekaligus pedoman untuk selanjutnya guru dan sekolah diharapkan memberikan motivasi belajar lebih kepada siswa yang disertai dengan bimbingan dan pembinaan secara berkesinambungan dan berkelanjutan. Pemberian motivasi tersebut dirasa penting karena tanpa adanya motivasi dari pihak guru dan sekolah maka minat siswa dalam belajar akan kurang optimal dan akan berpengaruh terhadap hasil belajarnya. 3) Kepada Siswa/i Kelas V. Siswa diharapkan untuk memotivasi dirinya sendiri dan teman-temannya untuk giat dalam belajar di sekolah maupun belajar di rumah, serta selalu berupaya membangkitkan minat belajar dan meningkatkan hasil belajarnya tidak hanya pada mata pelajaran IPA tetapi juga pada mata pelajaran yang lainnya.

\section{Daftar Pustaka}

Arikunto, Suharismi. (2006). Prosedur Penelitian Suatu Pendekatan Praktek. Jakarta: Rineka Cipta. Dalyono. (2012). Psikologi Pendidikan. Jakarta: Rineka Cipta.

Depdiknas. (2003). Undang-Undang Sistem Pendidikan Nasional No. 20 Tahun 2003. Jakarta. Depdiknas. Djaali. (2008). Psikologi Pendidikan. Jakarta: Bumi Aksara.

Djamarah. (2008). Psikologi Belajar. Jakarta: PT. Rineka Cipta.

Koyan, I Wayan. (2012). Statistik Pendidikan: Tehnik Analisis Data Kuantitatif. Universitas Pendidikan Ganesha Press.

Laksana, D.N L. (2017). The Effectiveness of Inquiry Based Learning for Natural Science Learning in Elementary School. Journal of Education Technology, 1(1), 1-5.

Margono. (2010). Metodologi Penelitian Pendidikan. Jakarta: Rineka Cipta

Prihantoro. (2010). Model Pembelajaran Terpadu.Jakarta. PT.Bumi Aksara

Purwanto. (2013). Evaluasi Hasil Belajar. Yogyakarta: Pustaka Pelajar

Riduwan. (2009). Metode \& Teknik Menyusun Proposal Penelitian, Bandung: Alfabeta.

Sardiman, A.M. 2012. Interaksi dan Motivasi Belajar Mengajar. Jakarta: CV Rajawali.

Slameto. (2010). Belajar dan Faktor-faktor yang Mempengaruhinya. Jakarta : PT. Rineka Cipta.

Slameto.(2010). Belajar dan Faktor-faktor yang Mempengaruhinya. Jakarta: Bumi Aksara.

Sugiyono. (2012). Metode Penelitian Pendidikan Pendekatan Kuantitatif, Kualitatif dan R\&D. Bandung: Alfabeta.

(2001). Statistika Untuk Penelitian. Bandung: Alfabeta.

(2010). Metode Penelitian Pendidikan. Bandung: Alfabeta.

(2010). Statistika Untuk Penelitian. Bandung: Alfabeta.

Sukardi. (2003). Bimbingan dan Penyuluhan Belajar di Sekolah. Bandung : Usaha Nasional. . (2012). Metodologi Penelitian Pendidikan. Jakarta: Bumi Aksara.

Susanto. (2013). Teori Belajar dan Pembelajaran di Sekolah Dasar.Jakarta: Kencana Prenada Media Group.

Trianto. (2014). Model Pembelajaran Terpadu. Bumi Aksara: Jakarta.

Uno. (2012). Teori Motivasi \& Pengukurannya. Jakarta. Bumi Aksara. 